\title{
Addressing intravaginal practices in women with HIV and at-risk for HIV infection, a mixed methods pilot study
}

This article was published in the following Dove Press journal:

International Journal of Women's Health

28 February 2017

Number of times this article has been viewed

\author{
Maria L Alcaide' \\ Violeta J Rodriguez ${ }^{2}$ \\ Margaret A Fischl' \\ Deborah L Jones ${ }^{2}$ \\ Stephen MWeiss ${ }^{2}$
}

'Division of Infectious Diseases, Department of Medicine, University of Miami Miller School of Medicine, ${ }^{2}$ Department of Psychiatry and Behavioral Sciences, University of Miami Miller School of Medicine, Miami, FL, USA
Correspondence: Stephen M Weiss Department of Psychiatry and Behavioral Sciences, University of Miami Miller School of Medicine 1400 NW 10th Avenue, Suite 404-A, Miami, FL 33I36, USA $\mathrm{Tel}+\mathrm{I} 3052432188$

Email sweiss2@med.miami.edu

\begin{abstract}
Intravaginal practices (IVPs), include intravaginal cleansing (cleansing the inside of the vagina) or intravaginal insertion of products for hygiene, health or sexuality reasons. IVPs are associated with adverse female health outcomes, development of bacterial vaginosis, HIV acquisition and transmission. A mixed methods approach was used in this study to examine the prevalence of IVP, assess reasons for engagement, and perceptions of IVP among a sample of minority (African-American and Hispanic) women infected, or at-risk, for HIV in Miami, USA, a city with increasing numbers of sexually transmitted infections (STIs) and HIV. Three focus groups (total $n=20)$ and quantitative assessments $(n=72)$ were conducted with women infected or uninfected with HIV. In the qualitative assessments, most women reported engaging in both intravaginal cleansing and intravaginal insertion, and stated the main motivation for IVP was hygiene. The quantitative assessments confirmed that cleansing with water alone, soap with water or using commercial douches was common, as well as intravaginal insertion using a cloth or a rag in both HIV-infected and uninfected women. Women with HIV infection reported less use of water and water and soap for IVPs, and reported learning about the potential harm of IVP from their HIV health care providers. Despite their health risks, IVP appeared common in both HIV-infected and at-risk minority women, and interventions to decrease IVP could have important health implications among populations with high rates of IVP, STIs and HIV.
\end{abstract}

Keywords: focus groups, HIV, vaginal practices, women, mixed methods

\section{Introduction}

Vaginal practices are used by large numbers of women worldwide to clean, tighten, dry or warm the vagina to enhance hygiene, health or sex. ${ }^{1}$ Intravaginal practices (IVPs) refer to both intravaginal cleansing (cleaning or washing inside the vagina with fingers or other substances to remove fluids), and intravaginal insertion (placing something inside the vagina, eg, powders, creams, or tissue). ${ }^{1}$ In the US, intravaginal cleansing with commercial douches is common among African-Americans and Hispanics, and is one of the primary risk factors for bacterial vaginosis (BV), the most common genital infection in women of childbearing age. ${ }^{2-5} \mathrm{BV}$ is associated with adverse health outcomes, eg, preterm delivery and gynecological surgery complications. ${ }^{2,6,7}$ BV has also been shown to increase the risk of acquisition and transmission of sexually transmitted infections (STIs) and HIV. ${ }^{2,8-11}$ Likewise, IVPs, independent of BV, have been associated with an increased risk for HIV acquisition. ${ }^{10,12-14}$ IVPs are therefore important to evaluate in women with HIV and at-risk for HIV infection as they are associated with women's poor health outcomes and are likely implicated in both HIV acquisition and transmission to sexual partners. 
IVPs have previously been studied in settings with high HIV rates. In sub-Saharan Africa, IVPs are used for cleansing, and intravaginal insertion is used to create a warm and tight vaginal environment to please male partners, a partner preference associated with traditional and cultural expectations of women. ${ }^{15-17}$ Among HIV-uninfected women in the US, douching is common and primarily motivated by vaginal hygiene. ${ }^{18,19}$ Few studies have addressed IVP among HIVinfected women, in whom IVP may be implicated in the development of BV, obstetric and gynecological complications, and HIV transmission. ${ }^{2,6-11}$

Miami, a large urban center located in the southeastern US with a diverse population, has a high prevalence of STIs and HIV, and is ranked number one for new HIV cases in the metropolitan US. ${ }^{20}$ This study used a mixed methods approach to examine the prevalence of IVP, assess reasons for engagement, and perceptions of IVP among HIV-infected and HIV-uninfected women in Miami, FL, USA, a racially and ethnically diverse city with increasing numbers of STIs and HIV. Findings from this study may provide a basis to identify IVP-reduction strategies among HIV-infected and HIV-uninfected ethnic and racial minority women living in US cities with a high prevalence of HIV and STIs.

\section{Methods}

This study was conducted as part of a larger study evaluating the effect of IVPs on the vaginal mucosa in HIV-infected and uninfected women in Miami, FL, USA. ${ }^{21,22}$ The study was conducted at the University of Miami AIDS Clinical Research and Behavioral Research Units, in collaboration with the Miami Women's Interagency HIV Study (WIHS) and the Miami Center for AIDS Research, from January 2014 to December 2015. The WIHS study is a large multicenter cohort of women with HIV infection or at-risk for HIV infection. Details of the WIHS study have been previously described. ${ }^{23}$ This study utilized a mixed methods approach to evaluate IVPs. The qualitative component of this study included focus groups discussions (FGDs) and was conducted in the University of Miami AIDS behavioral research unit. This unit is equipped with large meeting areas where confidentiality is preserved. The quantitative component of this study was conducted at the Miami Center for AIDS research clinical research unit, in private offices. Each participant was interviewed independently in a closed room and confidentiality was preserved at all times.

This research involves human participants and approval from the University of Miami Institutional Review Board was obtained prior to conducting any study-related procedures.
The research has been performed in accordance with the ethical standards as laid down in the 1964 Declaration of Helsinki and its later amendments or comparable ethical standards. Written informed consent was obtained from all participants at study enrollment.

\section{Recruitment strategy and study design}

A convenience sample was recruited by the study coordinator from local HIV and community clinics, partially recruited face-to-face in collaboration with the WIHS, or referred by local community agencies; further detail regarding recruitment and participant medical history based on primary data collection has been previously published. ${ }^{21,22}$ The inclusion criteria included being at least 18 years of age, and having had vaginal intercourse in the 3 months prior to enrollment. Participants were rewarded with US\$25. Participants completing the quantitative questionnaires were compensated US\$50 for time and transportation. The study used a mixed methods cross-sectional study.

\section{Qualitative data collection}

Qualitative data was collected by FGDs. To allow theoretical saturation, three FGDs with women were conducted (two in English and one in Spanish) using a semi-structured guide that addressed feminine hygiene and vaginal health; rationale, perceptions, and type of practices used for IVP; cultural norms and beliefs; concerns about discontinuing IVP (Table 1). The average FGD duration was 56 minutes. HIV status disclosure or IVP use were not required for participation in the FGDs. FGDs were led by two doctorallevel female facilitators, in order to enhance disclosure, who defined IVP as "the insertion of products inside the vagina for hygiene, health or sexual pleasure", clarified that IVP included both intravaginal cleansing and insertion and mentioned different practices. A three-dimensional model of the female genital anatomy was used to emphasize that IVP did not include external cleansing of the female genitalia. The stem questions were developed collaboratively by the investigators using data from a previous pilot study in Zambia, ${ }^{15,19,24}$ and were designed to identify modifiable risk factors that could be used in IVP-reduction interventions.

\section{Quantitative data collection}

Quantitative assessments were conducted using Qualtrics web-based software (Qualtrics 2015, Provo, UT, USA) for data entry by the study coordinator, who verbally asked participants each question. Quantitative IVP measures were 
Table I Focus group discussion questions and responses

\begin{tabular}{|c|c|c|}
\hline Topics & Focus group discussion questions & Summary of responses \\
\hline $\begin{array}{l}\text { Feminine hygiene } \\
\text { and vaginal health }\end{array}$ & $\begin{array}{l}\text { Can you describe what vaginal hygiene is? } \\
\text { Have you heard of bacterial vaginosis? } \\
\text { What do women do when they have an infection or think there is } \\
\text { something wrong in the vagina? } \\
\text { Are IVPs good for women's health? }\end{array}$ & $\begin{array}{l}\text { Vaginal hygiene is an essential part of women' health } \\
\text { and necessary to stay clean. } \\
\text { Infections occur when women do not take proper care } \\
\text { of the vagina. }\end{array}$ \\
\hline $\begin{array}{l}\text { Rationale, } \\
\text { perceptions and } \\
\text { types of practices }\end{array}$ & $\begin{array}{l}\text { Why do women engage in IVPs? } \\
\text { When do women engage in IVPs? } \\
\text { What products women use for IVPs for different purposes? } \\
\text { Have you ever heard of products to dry the vagina or make it tight or } \\
\text { change the feeling for men? } \\
\text { Have you ever heard of placing drugs such as cocaine inside the vagina? } \\
\text { Do you think men like that women engage in IVPs? } \\
\text { How old are women when they start doing IVPs? }\end{array}$ & $\begin{array}{l}\text { Women engage in IVP for hygiene purposes, primarily to } \\
\text { clean after menses. They also use intravaginal cleansing } \\
\text { to be cleaned prior to sex. Women use different } \\
\text { products: vaginal douches, soap and water, vinegar. } \\
\text { Vinegar is used to tighten the vagina. } \\
\text { Hispanic Caribbean women engage in intravaginal } \\
\text { insertion of products that are brought from their } \\
\text { countries of origin. }\end{array}$ \\
\hline $\begin{array}{l}\text { Cultural norms } \\
\text { and beliefs }\end{array}$ & $\begin{array}{l}\text { How do women learn about IVPs? } \\
\text { Are men aware women engage in IVPs? } \\
\text { Do you think IVPs are a cultural thing? }\end{array}$ & $\begin{array}{l}\text { Women learn IVP from mothers or older sisters at the } \\
\text { time of the initiation of menstruation. } \\
\text { IVPs are practiced by women of all cultures. }\end{array}$ \\
\hline Discontinuing IVP & $\begin{array}{l}\text { If vaginal practices are bad for women, would women continue doing } \\
\text { them? } \\
\text { How would women feel if not doing IVPs would affect how clean they } \\
\text { feel, or their sex life? } \\
\text { What would make women stop doing IVPs? }\end{array}$ & $\begin{array}{l}\text { Women with HIV infection were aware of the health } \\
\text { consequences of IVP. Both HIV-infected and uninfected } \\
\text { women stated discontinuing IVP is difficult. }\end{array}$ \\
\hline
\end{tabular}

Abbreviation: IVP, intravaginal practice.

developed by the study team and have previously been used in other settings ${ }^{16}$ but were adapted using FGD data. The questionnaire assessed lifetime IVP use, age of and reason for IVP initiation and continuation, person who educated them on IVP and products used in the prior month.

\section{Demographics and sexual risk factors and medical history}

Demographic, medical history, sexual risk factors questions included age, race, ethnicity, marital status, education, employment, monthly income, number of partners in the prior 5 years, condom use, lifetime exchange of sex for compensation, and history of STIs (Table 2).

HIV testing was performed by using the rapid test OraQuick Advance ${ }^{\circledR}$ Rapid HIV-1/2 Antibody Test. If positive, a confirmatory HIV Western blot was performed. HIV-infected women presented documentation of HIV infection.

\section{Data analysis Qualitative data analysis}

Audio recordings, written notes, and brief summaries were collected for each FGD. Audio recordings were transcribed and coded using NVIVO8 software; coding themes were identified based on summaries, direct quotes, and previous research. ${ }^{16}$ Data were coded and analyzed using grounded theory ${ }^{25}$ by three team members and consensus on themes and coding was reached through frequent collaborative discussions.

\section{Quantitative data analysis}

Univariate and bivariate analyses were used to describe demographic characteristics, IVP use and perceptions, frequency, and reasons for use of IVP, and compare responses by HIV status; demographic and medical history variables were also compared by whether the participant reported douching. Chi-square tests were used for comparisons. Statistical Package for the Social Sciences (SPSS) Version 22.0 (IBM Corp., Armonk, NY, USA) was used for all analyses. A threshold of $P<0.05$ was used to determine statistical significance.

\section{Results Qualitative results}

Focus group discussions participants

Twenty women participated in the FGDs. Women's median age was 44 years ( $\mathrm{SD}=8.5$ years). Half of the women were African-American and the other half were Hispanic; $70 \%$ were HIV infected. Most women ( $\sim 80 \%)$ reported having engaged in IVP. Both within-group and across-group saturation were achieved. A summary of the responses is presented in Table 1 .

\section{Perceptions of IVP and rationale for IVP}

Reasons for engagement in IVP were diverse and primarily related to personal hygiene. All women indicated that vaginal hygiene was an essential component of women's health. About half reported using intravaginal cleansing primarily to remove blood after menses, to be "ready" for their male 
Table 2 Sociodemographic characteristics and medical history $(\mathrm{N}=72)$

\begin{tabular}{|c|c|c|c|c|}
\hline Characteristics & $\begin{array}{l}\text { All } \\
\text { n (\%) } \\
\text { Mean (SD) }\end{array}$ & $\begin{array}{l}\text { HIV- }(n=27) \\
n(\%) \\
\text { Mean (SD) }\end{array}$ & $\begin{array}{l}\text { HIV+ }(n=45) \\
n(\%) \\
\text { Mean (SD) }\end{array}$ & $\begin{array}{l}\chi^{2} / t / Z \\
P \text {-value }\end{array}$ \\
\hline Age & 34.17 (7.30) & $34.88(6.32)$ & $34.80(7.87)$ & $0.22,0.829$ \\
\hline \multicolumn{4}{|l|}{ Race } & $1.5 \mathrm{I}, 0.468^{\mathrm{a}}$ \\
\hline Black & $55(76.4)$ & $19(70.4)$ & $36(80.0)$ & \\
\hline White & $12(16.7)$ & $5(\mid 8.5)$ & $7(\mid 5.6)$ & \\
\hline Mixed or other & $5(6.9)$ & $3(\mid I . I)$ & $2(4.4)$ & \\
\hline \multicolumn{4}{|l|}{ Ethnicity } & $8.02,0.035^{a}$ \\
\hline Hispanic & $13(18.1)$ & $8(29.6)$ & $5(I I . I)$ & \\
\hline Non-Hispanic & $46(63.9)$ & $16(59.3)$ & $30(66.7)$ & \\
\hline Haitian & $7(9.7)$ & $0(0.0)$ & $7(15.6)$ & \\
\hline Other & $6(8.3)$ & $3(I I .1)$ & $3(6.7)$ & \\
\hline \multicolumn{4}{|l|}{ Marital status } & $0.84,0.692^{\mathrm{a}}$ \\
\hline Never married & $28(40.6)$ & $12(46.2)$ & $16(37.2)$ & \\
\hline Stable partnership & $8(11.6)$ & $2(7.7)$ & $6(14.0)$ & \\
\hline Unstable partnership & $33(47.8)$ & $12(46.2)$ & $21(48.8)$ & \\
\hline \multicolumn{4}{|l|}{ Educational level } & $5.70,0.017$ \\
\hline High school or less & $51(71.8)$ & $15(55.6)$ & $36(81.8)$ & \\
\hline More than high school & $20(28.2)$ & $12(44.4)$ & $8(18.2)$ & \\
\hline \multicolumn{4}{|l|}{ Employed } & $1.35,0.246$ \\
\hline No & $53(76.8)$ & I8 (69.2) & $35(81.4)$ & \\
\hline Yes & $16(23.2)$ & $8(30.8)$ & $8(18.6)$ & \\
\hline \multicolumn{4}{|c|}{ Monthly household income (US\$) } & $7.25,0.007$ \\
\hline$\leq 1,200$ & $50(72.5)$ & $14(53.8)$ & $36(83.7)$ & \\
\hline$>1,200$ & $19(27.5)$ & $12(46.2)$ & $7(16.3)$ & \\
\hline Partners past 5 years & $10.67(21.29)$ & $16.93(28.50)$ & $6.91(14.59)$ & $1.12,0.262^{b}$ \\
\hline \multicolumn{4}{|c|}{ Condom use in the prior month } & $8.61,0.014$ \\
\hline Always & $35(50.0)$ & $9(33.3)$ & $26(60.5)$ & \\
\hline Sometimes & $13(18.6)$ & $4(14.8)$ & $9(20.9)$ & \\
\hline Never & $22(31.4)$ & $14(5 \mid .9)$ & $8(18.6)$ & \\
\hline \multicolumn{4}{|c|}{ Lifetime exchange of sex for compensation } & $0.76,0.363$ \\
\hline No & $44(62.0)$ & $15(55.6)$ & $29(65.9)$ & \\
\hline Yes & $27(38.0)$ & $12(44.4)$ & $15(34.1)$ & \\
\hline \multicolumn{4}{|l|}{ History of gonorrhea } & $4.00,0.046$ \\
\hline No & $58(80.6)$ & $25(92.6)$ & $33(73.3)$ & \\
\hline Yes & $14(19.4)$ & $2(7.4)$ & $12(26.7)$ & \\
\hline \multicolumn{4}{|l|}{ History of chlamydia } & $0.44,0.602$ \\
\hline No & $50(69.4)$ & $20(74.1)$ & $30(66.7)$ & \\
\hline Yes & $22(30.6)$ & $7(25.9)$ & $15(33.3)$ & \\
\hline \multicolumn{4}{|l|}{ History of syphilis } & $6.01,0.014$ \\
\hline No & $59(81.9)$ & $26(96.3)$ & $33(73.3)$ & \\
\hline Yes & $13(18.1)$ & I (3.7) & $12(26.7)$ & \\
\hline \multicolumn{4}{|l|}{ History of genital herpes } & $0.5 \mathrm{I}, 0.704$ \\
\hline No & $65(90.3)$ & $25(92.6)$ & $40(88.9)$ & \\
\hline Yes & $7(9.7)$ & $2(7.4)$ & $5(11.1)$ & \\
\hline \multicolumn{4}{|l|}{ History of trichomoniasis } & $0.01,1.000$ \\
\hline No & $53(73.6)$ & $20(74.1)$ & $33(73.3)$ & \\
\hline Yes & $19(26.4)$ & $7(25.9)$ & $12(26.7)$ & \\
\hline
\end{tabular}

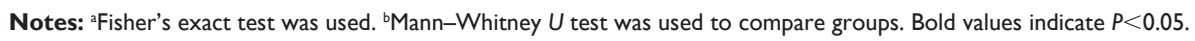

partner, including removing unpleasant odor/discharge before sexual intercourse. More than half of the women stated they engage in intravaginal cleansing after menses, and about $30 \%$ of women more frequently than post-menses alone.

A woman needs to be cleaned and douching needs to be done because women are women. [HIV-uninfected woman, Spanish FGD]
Yeah, the question is, sometimes women get like a discharge, they don't know what it is, so they go and get a douche to clean it out... also, the smell, the odor ... you have to rinse it out and then you will smell good. [HIV-infected woman, English FGD]

Approximately $50 \%$ of women reported intravaginal cleansing prior to sex to be clean. One woman stated some 
women use intravaginal insertion of different products with new partners to tighten the vagina so men would not think they had other partners:

You need to clean the inside if there is a lot of fluid or if you plan on having sex that day so the man does not think you are sleeping with other men. [HIV-uninfected woman, Spanish FGD]

If you're cheating, you gonna do it... you don't want him to know that you had sex with somebody else, and you go in there with vinegar and water before you get to see him. [HIV-infected woman, English FGD]

About $30 \%$ of the women knew that the vagina has bacteria that keep it healthy and a balanced $\mathrm{pH}$ was important to achieve vaginal health, commenting:

We have bacteria that keep us healthy. And because we are open, we can get anything. We have to wear light panties, nothing heavy, and nothing tight, and clean very well. [HIV-uninfected woman, English FGD]

\section{Types of practices, cultural beliefs regarding IVP} Women reported using different products for different purposes. The products most commonly used for intravaginal cleansing were commercial vaginal douches, followed by water and soap, and homemade vaginal douches. The most commonly cited household product ( $50 \%$ ), apart from soap and water was vinegar, used for tightening the vagina. Intravaginal insertion of cloths or rags was also common. Caribbean Hispanic women cited household cleansing products used for intravaginal insertion in their countries as "blue bomba soap" and "guava soap" (in the Dominican Republic and Haiti). A variety of intravaginal cleansing methods were reported:

I mix soap and water in a plastic bottle and then I rinse and wash inside. [HIV-uninfected woman, Spanish FGD]

Vinegar and water you can use to tighten up. You put it in a bottle with water and some vinegar inside, and then flush it in. Because vinegar and water will dry it out. [HIVuninfected woman, English FGD]

Women perceived engaging in IVP as a cross-cultural practice among women, rather than specific to their own culture. IVP for cleansing purposes was often introduced to women by their mothers, older sisters, or sex education teachers. Most women started engaging in intravaginal cleansing after menarche (ages 9 to 14 years). Though perceived as universal, different cultures used different products for IVP, particularly for sexual partner pleasure:

I learned when I was in school and I took sex education classes... and then, my menstruation went off and my mother, she would go to the store and showed me the different products. So, you know, that's how I learned how to clean my stuff up. You know, with the classes and my mother. [HIV-uninfected woman, English FGD]

It may be a cultural thing; it may be not. I just think is part of being a woman. [HIV-infected woman, Spanish FGD]

\section{Health consequences, concerns regarding discontinuation of IVP}

Many women were aware that intravaginal cleansing could be harmful and had been instructed to discontinue intravaginal cleansing in the past and informed of the health consequences by their health care providers. Most HIV-infected women had engaged in IVP prior to HIV-infection, but said they had discontinued the practice after learning of its negative consequences:

... and then when I tell her [my doctor] that I was using the feminine washes inside that was a "No" [loud]. I was putting it inside. She [my doctor] said, "No you can use it if you want but just outside with water only". [HIV-uninfected woman, English FGD]

Things we have learned because of our [HIV] diagnosis is how to take care of ourselves ... other women don't have support groups where they learn. [HIV-infected woman, English FGD]

I used to douche two times a week. Then I started getting fluid drains and sores on my vagina so I went to my doctor. My doctor said: stop using douches, it is not helping you. I stopped and it worked out ok. [HIV-infected woman, English FGD]

I did not learn from my doctor. I went to the group [HIV support group] and I told the lady [counselor] that I douched every month and when I have intercourse, and that I keep myself very clean. They said, that was not good. [HIV-infected woman, English FGD]

Women who had been advised to discontinue intravaginal cleansing stated it was difficult to stop and some still engaged in IVP due to anxiety that they would not feel clean. Other women felt discontinuation of IVP required discussion with the doctor as to why IVP was not healthy, stating:

Douching? I heard some doctors and others say that it's bad but... I do it still once a month. But if my doctor said 
"now it is going to kill you"... then maybe I would stop.

[HIV-infected woman, English FGD]

It is like a mental thing, a habit. You just douche for fun. And it will be difficult to stop. [HIV-uninfected woman, Spanish FGD]

\section{Quantitative results}

\section{Participant demographics and medical history}

IVP questionnaires were completed by 72 women, mean age was 34.17 years ( $\mathrm{SD}=7.30$ years). Forty-five $(63 \%)$ women were HIV infected. Three-quarters were Black, mostly non-Hispanic (African-American and Haitians). Nearly half were in a stable partnership. About three-quarters had low education levels (high school or less), income below the poverty level (USD \$1,200/month), and were unemployed. The median number of sexual partners in the prior 5 years was high (11 partners) and only half reported always using a condom in the prior month. Almost $40 \%$ reported having exchanged sex for compensation in the past. About 20\% of women reported a history of gonorrhea or syphilis, $31 \%$ chlamydia, $10 \%$ genital herpes, and 26\% trichomoniasis.

All HIV-infected women were receiving antiretrovirals. In comparison to their HIV-uninfected counterparts, HIVinfected women were primarily Black non-Hispanic, had lower education and income, used condoms more consistently, and more reported having a history of gonorrhea or syphilis (Table 2). No demographic or medical history differences emerged between women reporting douching in the past month and those who did not.

\section{Intravaginal practices}

Most (85\%) women reported lifetime IVP use, began using them at a mean age of 18 years, engaged in IVP for hygiene and learned IVP from their mothers or friends. IVPs were most commonly practiced using fingers alone, followed by water alone, soap alone or soap with water, insertion of a cloth/rag, commercial douches, vinegar, and homemade douches. Women that used fingers, water, soap, and a cloth or a rag reported engaging in this IVP daily; commercial douches were primarily used weekly; and vinegar or homemade douches were used monthly or less. The primary motivator for most products was hygiene; homemade douches were primarily used to prevent pregnancy. Only one woman reported having inserted herbs for IVP in the prior month, reportedly for hygiene purposes. HIV-infected women reported less use of IVP water and soap or soap with water for IVP. There were no differences in reasons for IVP engagement by HIV status. Further detail by HIV status is presented in Table 3.

Most women reported that they would discontinue the use of IVP if it was harmful. The most difficult IVP to discontinue would be vaginal douches. There were no differences regarding discontinuation by HIV status (Table 4).

\section{Discussion}

This study explored beliefs regarding IVP and methods of intravaginal cleansing among HIV infected and uninfected, African-American and Hispanic women, in an urban setting with high rates of HIV and STIs, in the US. IVPs were common and used primarily for hygiene. Women started IVPs at an early age; cleansing with water alone or soap with water was more common than commercial douches. More than half of the participants used IVP daily or weekly. HIVinfected women used less water and less water with soap for IVPs, and appeared more aware of the deleterious health consequences of IVP.

Consistent with previous reports in the US, most women used intravaginal cleansing for hygiene, ${ }^{26}$ and less commonly to please sexual partners or for health-related concerns. This contrasts with studies from other regions in the world such as sub-Saharan Africa, where the primary motivator for IVP is male partner pleasure..$^{15,27-29}$ Most studies in the US have evaluated the use of intravaginal douches, but not the use of other products which can also affect the vaginal mucosa and place women at-risk. In our study, we also assessed other household products and intravaginal insertion of a cloth or a rag for cleansing purposes. While African-American women reported frequent use of commercial douches, household products such as soap, cloths, or a rag, vinegar and homemade douches, were utilized by Hispanic women. The broad spectrum of IVP among diverse women in our sample, and the use of different products by women of different ethnicities, suggest that further research is needed to explore the scope of this practice in a larger study population, to better assess health disparities as a function of race and ethnicity, and to better understand implications for STIs and HIV transmission. In addition, interventions to decrease IVP in the US have seldom been studied, ${ }^{30}$ and focused primarily on vaginal douching. Our findings highlight that interventions to reduce IVPs using vaginal douches need to be developed and tested in US communities with high rates of STIs and HIV.

Though HIV-infected FGD participants were aware that IVP could be harmful and indicated that they had reduced IVP subsequent to provider health instructions, this message did not appear to be sufficient to motivate women 
Table 3 Intravaginal practices: lifetime use of IVP, past month use, frequency and reasons for use of intravaginal practices by product $(\mathrm{N}=72)$

\begin{tabular}{|c|c|c|c|c|}
\hline Intravaginal practices & $\begin{array}{l}\text { All }(N=73) \\
n(\%)\end{array}$ & $\begin{array}{l}\text { HIV- }(n=27) \\
n(\%)\end{array}$ & $\begin{array}{l}\text { HIV+ }(n=46) \\
n(\%)\end{array}$ & $\chi^{2}, P$-value \\
\hline Lifetime use of IVP & $62(84.7)$ & $25(92.6)$ & $36(80.0)$ & $\mathrm{FET}, 0.19 \mathrm{I}^{\mathrm{a}}$ \\
\hline Age of first time use (years) & I8.03 (5.07) & $18.27(5.15)$ & $17.87(5.07)$ & FET, $0.772^{\mathrm{a}}$ \\
\hline \multicolumn{5}{|l|}{ Reasons for first use of IVP } \\
\hline General hygiene & $61(83.6)$ & $24(88.9)$ & $37(80.4)$ & \\
\hline To please sex partner & $2(2.7)$ & I (3.7) & $\mathrm{I}(2.2)$ & \\
\hline Has never practiced & $10(13.7)$ & $2(7.4)$ & $8(17.4)$ & $1.69,0.396$ \\
\hline \multicolumn{5}{|l|}{ How they learned of IVP } \\
\hline Mother & $26(36.1)$ & $10(37.0)$ & $16(35.6)$ & \\
\hline Relative & $7(9.7)$ & $3(I I . I)$ & $4(8.9)$ & \\
\hline Friend & $18(25.0)$ & $8(29.6)$ & $10(22.2)$ & \\
\hline Cultural & $2(2.8)$ & I (3.7) & $\mathrm{I}(2.2)$ & \\
\hline Doctor/nurse & $5(6.9)$ & I (3.7) & $4(8.9)$ & \\
\hline Their own idea & $13(18.1)$ & $4(14.8)$ & $9(20.0)$ & \\
\hline Never heard of IVP & I (I.4) & $0(0.0)$ & $\mathrm{I}(2.2)$ & $\mathrm{FET}, 0.950^{\mathrm{a}}$ \\
\hline \multicolumn{5}{|l|}{ Product used of IVP in the prior month } \\
\hline \multicolumn{5}{|l|}{ Fingers } \\
\hline Used fingers in the past month & $29(40.3)$ & $10(34.5)$ & $19(65.5)$ & FET, $0.664^{a}$ \\
\hline \multicolumn{5}{|l|}{ Frequency of fingers use } \\
\hline Daily & $13(17.8)$ & $3(I I .1)$ & $10(21.7)$ & \\
\hline Weekly & $4(5.5)$ & I (3.7) & $3(6.5)$ & \\
\hline Monthly & $8(11.0)$ & $4(14.8)$ & $4(8.7)$ & \\
\hline Less than monthly & $4(5.5)$ & $2(7.4)$ & $2(4.3)$ & \\
\hline Never & $44(60.3)$ & $17(63.0)$ & $27(58.7)$ & $4.24,0.724$ \\
\hline \multicolumn{5}{|l|}{ Reasons for using fingers } \\
\hline General hygiene & $25(34.2)$ & $8(29.6)$ & $17(37.0)$ & \\
\hline To please sex partner & $4(5.5)$ & $2(7.4)$ & $2(4.3)$ & \\
\hline Never used fingers as IVP & $44(60.3)$ & $17(63.0)$ & $27(58.7)$ & $0.6 \mathrm{I}, 0.723^{\mathrm{a}}$ \\
\hline Water & & & & FET, $0.024^{\mathrm{a}}$ \\
\hline Used water in the past month & $27(37.5)$ & $15(55.6)$ & $12(27.3)$ & \\
\hline \multicolumn{5}{|l|}{ Frequency of water use } \\
\hline Daily & $17(23.3)$ & $9(33.3)$ & $8(17.4)$ & \\
\hline Weekly & $2(2.7)$ & I (3.7) & $I(2.2)$ & \\
\hline Monthly & $7(9.6)$ & $3(11.1)$ & $4(8.7)$ & \\
\hline Less than monthly & $3(4.1)$ & $2(7.4)$ & $\mathrm{I}(2.2)$ & \\
\hline Never & $44(60.3)$ & $12(44.4)$ & $32(69.6)$ & $\mathrm{FET}, 0.218^{\mathrm{a}}$ \\
\hline \multicolumn{5}{|l|}{ Reasons for using water } \\
\hline General hygiene & $28(38.4)$ & $14(5 \mid .9)$ & $14(30.4)$ & \\
\hline To prevent pregnancy & I (I.4) & I (3.7) & $0(0.0)$ & \\
\hline Never used water as IVP & $44(60.3)$ & $12(44.4)$ & $32(69.6)$ & $\mathrm{FET}, 0.057^{\mathrm{a}}$ \\
\hline \multicolumn{5}{|l|}{ Soap or soap with water } \\
\hline Used soap in the past month & $22(31.0)$ & $12(54.5)$ & $10(45.5)$ & FET, $0.048^{a}$ \\
\hline \multicolumn{5}{|l|}{ Frequency of soap use } \\
\hline Daily & $19(26.0)$ & $10(37.0)$ & $9(19.6)$ & \\
\hline Weekly & $2(2.7)$ & $2(7.4)$ & $0(0.0)$ & \\
\hline Monthly & $\mathrm{I}(\mathrm{I} .4)$ & $0(0.0)$ & $\mathrm{I}(2.2)$ & \\
\hline Never & $51(69.9)$ & $15(55.6)$ & $36(78.3)$ & FET, $0.038^{a}$ \\
\hline \multicolumn{5}{|l|}{ Reasons for using soap } \\
\hline General hygiene & $22(30.1)$ & $12(44.4)$ & $10(21.7)$ & \\
\hline To prevent pregnancy & $9(12.3)$ & $4(14.8)$ & $5(10.9)$ & \\
\hline Never used soap as IVP & $42(57.5)$ & II (40.7) & $31(67.4)$ & $\mathrm{FET}, 0.072^{\mathrm{a}}$ \\
\hline \multicolumn{5}{|l|}{ Clothes or rags (intravaginal insertion) } \\
\hline Used clothes, wipes, or rags in the past month & $18(25.4)$ & $8(29.6)$ & $10(22.7)$ & $0.42,0.580$ \\
\hline \multicolumn{5}{|l|}{ Frequency of cloths/wipes/rags use } \\
\hline Daily & $9(12.3)$ & $3(11.1)$ & $6(13.0)$ & \\
\hline Weekly & $7(9.6)$ & $3(11.1)$ & $4(8.7)$ & \\
\hline Monthly & $\mathrm{I}(\mathrm{l} .4)$ & I (3.7) & $0(0.0)$ & \\
\hline Less than monthly & $3(4.1)$ & $3(I I . I)$ & $0(0.0)$ & \\
\hline Never & $53(72.6)$ & $17(63.0)$ & $36(78.3)$ & $\mathrm{FET}, 0.1 \mathrm{I}^{\mathrm{a}}$ \\
\hline
\end{tabular}


Table 3 (Continued)

\begin{tabular}{|c|c|c|c|c|}
\hline Intravaginal practices & $\begin{array}{l}\text { All }(N=73) \\
n(\%)\end{array}$ & $\begin{array}{l}\text { HIV- }(n=27) \\
n(\%)\end{array}$ & $\begin{array}{l}\text { HIV+ }(n=46) \\
n(\%)\end{array}$ & $\chi^{2}, P$-value \\
\hline \multicolumn{5}{|l|}{ Reasons for using cloths/wipes/rags } \\
\hline General hygiene & $19(26.0)$ & $9(33.3)$ & $10(21.7)$ & \\
\hline To please sex partner & I (I.4) & I (3.7) & $0(0.0)$ & \\
\hline Never used cloths/wipes/rags as IVP & $53(72.6)$ & $17(63.0)$ & $36(78.3)$ & $\mathrm{FET}, 0.206^{\mathrm{a}}$ \\
\hline \multicolumn{5}{|l|}{ Commercial douche } \\
\hline Used commercial douche in the past month & $14(19.7)$ & $6(22.2)$ & $8(18.2)$ & FET, $0.762^{\mathrm{a}}$ \\
\hline \multicolumn{5}{|l|}{ Frequency of commercial douche use } \\
\hline Daily & $0(0.0)$ & $0(0.0)$ & $0(0.0)$ & \\
\hline Weekly & I (I.4) & $0(0.0)$ & $\mathrm{I}(2.2)$ & \\
\hline Monthly & $13(17.8)$ & $6(22.2)$ & $7(\mid 5.2)$ & \\
\hline Less than monthly & $8(11.0)$ & $3(11.1)$ & $5(10.9)$ & \\
\hline Never & $18(66.7)$ & I8 (66.7) & 33 (7I.7) & $\mathrm{FET}, 0.874^{\mathrm{a}}$ \\
\hline \multicolumn{5}{|l|}{ Reasons for using commercial douche } \\
\hline General hygiene & $23(3 \mid .5)$ & $10(37.0)$ & $13(28.3)$ & \\
\hline Never used a commercial douche as IVP & $50(68.5)$ & $17(67.0)$ & $33(7 / .7)$ & $\mathrm{FET}, 0.602^{\mathrm{a}}$ \\
\hline \multicolumn{5}{|l|}{ Vinegar } \\
\hline Used vinegar in the past month & $10(14.1)$ & $4(14.8)$ & $6(13.6)$ & FET, I.000 \\
\hline \multicolumn{5}{|l|}{ Frequency of vinegar use } \\
\hline Monthly & $4(5.5)$ & $3(I I . I)$ & $\mathrm{I}(2.2)$ & \\
\hline Less than monthly & $9(12.3)$ & $2(7.4)$ & $7(15.2)$ & \\
\hline Never practice IVP & $60(82.2)$ & $22(8 \mid .5)$ & $38(82.6)$ & FET, $0.244^{a}$ \\
\hline \multicolumn{5}{|l|}{ Reasons for using vinegar } \\
\hline General hygiene & $12(16.4)$ & $5(18.5)$ & $7(15.2)$ & \\
\hline To prevent pregnancy & $7(9.6)$ & $5(18.5)$ & $2(4.3)$ & \\
\hline Never used vinegar as IVP & $54(74.0)$ & $17(63.0)$ & $37(80.4)$ & FET, $0.126^{a}$ \\
\hline \multicolumn{5}{|l|}{ Homemade douche } \\
\hline Used homemade douche in the past month & $8(11.3)$ & $3(11.1)$ & $5(I I .4)$ & FET, I.000 \\
\hline \multicolumn{5}{|l|}{ Frequency of homemade douche use } \\
\hline Monthly & $5(6.8)$ & $3(I I . I)$ & $2(4.3)$ & \\
\hline Less than monthly & $5(6.8)$ & $0(0.0)$ & $5(10.9)$ & \\
\hline Never & $63(86.3)$ & $24(88.9)$ & $39(84.8)$ & FET, $0.164^{a}$ \\
\hline \multicolumn{5}{|l|}{ Reasons for using homemade douche } \\
\hline General hygiene & $9(12.3)$ & $3(I I . I)$ & $6(13.0)$ & \\
\hline To prevent pregnancy & $10(13.7)$ & $6(22.2)$ & $4(8.7)$ & \\
\hline Never used a homemade douche as IVP & $54(74.0)$ & $18(66.7)$ & $36(78.3)$ & $\mathrm{FET}, 0.170^{\mathrm{a}}$ \\
\hline
\end{tabular}

Notes: aFisher's exact test was used. Intravaginal insertion of herbs (traditional herbs or medicines from another country) were assessed but used only by one participant. The answers reported for frequency of IVP, reasons to engage in IVP or products used were those that were scored for at least one woman. Frequencies assessed were: daily, weekly, monthly, less than monthly, or never. Reasons assessed were: general hygiene, to get rid of a discharge, to remove blood after menses, to prevent pregnancy, to prevent STIs, and to please sexual partner. Bold values indicate $P<0.05$.

Abbreviations: FET, Fisher's exact test; IVP, intravaginal practice; STIs, sexually transmitted infections.

to discontinue IVP completely. Both HIV-infected and uninfected women indicated they would cease IVP if informed of potential harm even if difficult, suggesting that increasing knowledge about the harmful effects of IVP alone may not be sufficient. The gap between knowledge and behavior in health promotion has been well-established, and targeting self-efficacy rather than knowledge alone may increase health promotion program effectiveness to help individuals transition from knowledge to action to decrease harmful, high-risk behavior. ${ }^{31}$ Women may need to be provided with alternative tools for vaginal hygiene to achieve their "desired" vaginal state. HIV-infected women, who generally are connected to medical care and routine medical visits, appear to be receptive to messages delivered by health care providers. However, HIV-uninfected women who are not routinely followed in medical settings, may require IVP messages to be delivered differently (eg, social media), though cultural and local adaptability must be considered to maximize acceptability and uptake. ${ }^{32}$

This study is novel as it examined IVP and IVP-related attitudes among women with and without HIV infection from ethnically and racially diverse backgrounds and assessed IVP use besides vaginal douching alone. However, this study is limited by its small sample, and may not be generalizable to, or representative of other urban or non-urban US settings, and differences in IVP were not examined by ethnicity. Similarly, results may not reflect the opinions or practices of younger populations or other ethnic groups. Differing responses between quantitative and qualitative data suggest that results may have been influenced by social desirability 
Table 4 Discontinuation of intravaginal practices $(\mathrm{N}=72)$

\begin{tabular}{|c|c|c|c|c|}
\hline & $\begin{array}{l}\text { All }(\mathrm{N}=72) \\
\mathrm{n}(\%)\end{array}$ & $\begin{array}{l}\text { HIV- }(n=27) \\
\text { n (\%) }\end{array}$ & $\begin{array}{l}\text { HIV }+(n=45) \\
n(\%)\end{array}$ & $\begin{array}{l}\chi^{2}, \\
P \text {-value }\end{array}$ \\
\hline \multicolumn{4}{|c|}{ Whether participant would discontinue IVP if she knew IVP may be harmful } & FET, $0.78 I^{\mathrm{a}}$ \\
\hline Would stop & $49(70.0)$ & 20 (76.9) & $29(65.9)$ & \\
\hline Would do less & $15(2 \mid .4)$ & $5(19.2)$ & $10(22.7)$ & \\
\hline Would use different products & $2(2.9)$ & $0(0.0)$ & $2(4.5)$ & \\
\hline Would not change & $4(5.7)$ & I (3.8) & $3(6.8)$ & \\
\hline \multicolumn{4}{|c|}{ Difficulty of stopping use if informed of potential harm } & FET, $0.186^{a}$ \\
\hline Difficult given long history of use & $21(30.0)$ & $9(34.6)$ & $12(27.3)$ & \\
\hline Easy if harmful & $43(61.4)$ & $13(50.0)$ & $30(68.2)$ & \\
\hline Some would be easy, others not & $6(8.6)$ & $4(15.4)$ & $2(4.5)$ & \\
\hline \multicolumn{4}{|l|}{ IVP most difficult to discontinue } & FET, $0.259^{a}$ \\
\hline Vaginal douches & $27(38.0)$ & $10(37.0)$ & 17 (38.7) & \\
\hline Water alone & $8(\mathrm{II} .3)$ & $6(22.2)$ & $2(4.5)$ & \\
\hline Fingers & $8(11.3)$ & $2(7.4)$ & $6(13.6)$ & \\
\hline Soap or soap with water & $13(18.3)$ & $5(18.5)$ & $8(18.2)$ & \\
\hline Cloth, rag, or wipes (intravaginal insertion) & $3(4.2)$ & $2(7.4)$ & I (2.3) & \\
\hline Vinegar & $8(I 1.3)$ & $2(7.4)$ & $6(13.6)$ & \\
\hline
\end{tabular}

Note: 'Fisher's exact test was used.

Abbreviations: FET, Fisher's exact test; IVP, intravaginal practice.

bias. ${ }^{33}$ Future studies should consider audio computer assisted survey technology or self-administration techniques such as ACASI to minimize social desirability bias..$^{34,35}$

\section{Conclusion}

Influencing IVP should be considered in future research studies in the US as a potential addition to existing HIV prevention strategies for women. Despite the association between IVP and HIV acquisition, IVP are commonly used by HIV-infected and uninfected women and have received little attention in STI and HIV prevention. Interventions to decrease IVP involving women's health practitioners present an important initiative for US populations with high rates of IVP, STI, and HIV.

\section{Acknowledgments}

This work was supported by: Miami Center for AIDS Research (through a CFAR developmental award) under grant number P30AI073961; Women's Interagency HIV Study (WIHS) under grant number U01AI103397; and National Institutes of Health under grant number K23HD074489.

The authors thank all those in their research team at the University of Miami, community sites providing referrals, and the women participating in this study. The opinions reflected in this report are those of the authors and do not necessarily reflect those of the funding agencies and participating institutions.

\section{Disclosure}

The authors report no conflicts of interest in this work.

\section{References}

1. Martin Hilber A, Chersich MF, van de Wijgert JH, Rees H, Temmerman M. Vaginal practices, microbicides and HIV: what do we need to know? Sex Transm Infect. 2007;83(7):505-508.

2. Holmes K, Sparling P, Stamm W, et al. Sexually Transmitted Diseases. 4th ed. New York: McGraw-Hill; 2008.

3. Brotman RM, Klebanoff MA, Nansel TR, et al. A longitudinal study of vaginal douching and bacterial vaginosis - a marginal structural modeling analysis. Am J Epidemiol. 2008;168(2):188-196.

4. Clark RA, Theall KP, Amedee AM, Kissinger PJ. Frequent douching and clinical outcomes among HIV-infected women. Sex Transm Dis. 2007;34(12):985-990.

5. McKee MD, Baquero M, Anderson MR, Alvarez A, Karasz A. Vaginal douching among Latinas: practices and meaning. Matern Child Health J. 2009;13(1):98-106.

6. Wilson JD, Ralph SG, Jackson F, Rutherford AJ. Infertility, preterm birth, and bacterial vaginosis. Lancet. 1999;354(9177):511.

7. Chaim W, Mazor M, Leiberman JR. The relationship between bacterial vaginosis and preterm birth. A review. Arch Gynecol Obstet. 1997;259(2):51-58.

8. Fethers KA, Fairley CK, Hocking JS, Gurrin LC, Bradshaw CS. Sexual risk factors and bacterial vaginosis: a systematic review and metaanalysis. Clin Infect Dis. 2008;47(11):1426-1435.

9. Cu-Uvin S, Hogan JW, Caliendo AM, Harwell J, Mayer KH, Carpenter CC. Association between bacterial vaginosis and expression of human immunodeficiency virus type 1 RNA in the female genital tract. Clin Infect Dis. 2001;33(6):894-896.

10. Tsai CS, Shepherd BE, Vermund SH. Does douching increase risk for sexually transmitted infections? A prospective study in high-risk adolescents. Am J Obstet Gynecol. 2009;200(1):38 e31-e38.

11. Cohen CR, Lingappa JR, Baeten JM, et al. Bacterial vaginosis associated with increased risk of female-to-male HIV-1 transmission: a prospective cohort analysis among African couples. PLoS Med. 2012; 9(6):e1001251.

12. Low N, Chersich MF, Schmidlin K, et al. Intravaginal practices, bacterial vaginosis, and HIV infection in women: individual participant data meta-analysis. PLoS Med. 2011;8(2):e1000416.

13. McClelland RS, Lavreys L, Hassan WM, Mandaliya K, NdinyaAchola JO, Baeten JM. Vaginal washing and increased risk of HIV-1 acquisition among African women: a 10-year prospective study. AIDS. 2006;20(2):269-273. 
14. Myer L, Kuhn L, Stein ZA, Wright TC Jr, Denny L. Intravaginal practices, bacterial vaginosis, and women's susceptibility to HIV infection: epidemiological evidence and biological mechanisms. Lancet Infect Dis. 2005;5(12):786-794.

15. Alcaide ML, Chisembele M, Mumbi M, Malupande E, Jones D. Examining targets for HIV prevention: intravaginal practices in Urban Lusaka, Zambia. AIDS Patient Care STDS. 2014;28(3):121-127.

16. Alcaide ML, Mumbi M, Chitalu N, Jones D. Vaginal cleansing practices in HIV-infected Zambian women. AIDS Behav. 2013;17(3): 872-878.

17. Hassan WM, Lavreys L, Chohan V, et al. Associations between intravaginal practices and bacterial vaginosis in Kenyan female sex workers without symptoms of vaginal infections. Sex Transm Dis. 2007; 34(6):384-388.

18. Diclemente RJ, Young AM, Painter JL, Wingood GM, Rose E, Sales JM. Prevalence and correlates of recent vaginal douching among African American adolescent females. J Pediatr Adolesc Gynecol. 2012;25(1): 48-53.

19. Gazmararian JA, Bruce FC, Kendrick JS, Grace CC, Wynn S. Why do women douche? Results from a qualitative study. Matern Child Health J. 2001;5(3):153-160.

20. CDC. Center for Diseases Control. Diagnosis of HIV infections in the United States and Dependent Areas, 2014. HIV Surveillance Report; 2015;26. Available from http://www.cdc.gov/hiv/pdf/library/ reports/surveillance/cdc-hiv-surveillance-report-us.pdf. Accessed January 20, 2017.

21. Alcaide ML, Rodriguez VJ, Brown MR, et al. High levels of inflammatory cytokines in the reproductive tract of women with BV and engaging in intravaginal douching. A cross sectional study of participants in the Women Interagency HIV Study (WIHS). AIDS Res Hum Retroviruses. January 2017, ahead of print.

22. Alcaide ML, Strbo N, Romero L, et al. Bacterial Vaginosis Is Associated with Loss of Gamma Delta T Cells in the Female Reproductive Tract in Women in the Miami Women Interagency HIV Study (WIHS): A Cross Sectional Study. PLoS One. 2016;11(4):e0153045.

23. Hessol NA, Schneider M, Greenblatt RM, et al. Retention of women enrolled in a prospective study of human immunodeficiency virus infection: impact of race, unstable housing, and use of human immunodeficiency virus therapy. Am J Epidemiol. 2001;154(6):563-573.
24. Martin Hilber A, Hull TH, Preston-Whyte E, et al. A cross cultural study of vaginal practices and sexuality: implications for sexual health. Soc Sci Med. 2010;70(3):392-400.

25. Glaser BG. Grounded theory and gender relevance. Health Care Women Int. 2002;23(8):786-793.

26. Oh MK, Merchant JS, Brown P. Douching behavior in high-risk adolescents. What do they use, when and why do they douche? J Pediatr Adolesc Gynecol. 2002;15(2):83-88.

27. Esber A, Moyo P, Munjoma M, et al. Cessation of intravaginal practices to prevent bacterial vaginosis: a pilot intervention in Zimbabwean women. Sex Transm Infect. 2015;91(3):183-188.

28. Allen CF, Desmond N, Chiduo B, et al. Intravaginal and menstrual practices among women working in food and recreational facilities in Mwanza, Tanzania: implications for microbicide trials. AIDS Behav. 2010; 14(5):1169-1181.

29. Francis SC, Baisley K, Lees SS, et al. Vaginal practices among women at high risk of HIV infection in Uganda and Tanzania: recorded behaviour from a daily pictorial diary. PLoS One. 2013;8(3):e59085.

30. Grimley DM, Oh MK, Desmond RA, Hook EW, Vermund SH. An intervention to reduce vaginal douching among adolescent and young adult women: a randomized, controlled trial. Sex Transm Dis. 2005;32(12):752-758.

31. Rimal RN. Closing the knowledge-behavior gap in health promotion: the mediating role of self-efficacy. Health Commun. 2000; 12(3):219-237.

32. Castro FG, Barrera M, Martinez CR. The cultural adaptation of prevention interventions: resolving tensions between fidelity and fit. Prev Sci. 2004;5(1):41-45

33. Fisher RJ. Social desirability bias and the validity of indirect questioning. J Consum Res. 1993;20(2):303-315.

34. Krumpal I. Determinants of social desirability bias in sensitive surveys: a literature review. Quality \& Quantity. 2013;47(4):2025-2047.

35. Biddlecom AE. Trends in sexual behaviours and infections among young people in the United States. Sex Transm Infect. 2004;80:74-79.
International Journal of Women's Health

\section{Publish your work in this journal}

The International Journal of Women's Health is an international, peerreviewed open-access journal publishing original research, reports, editorials, reviews and commentaries on all aspects of women's healthcare including gynecology, obstetrics, and breast cancer. The manuscript management system is completely online and includes

\section{Dovepress}

a very quick and fair peer-review system, which is all easy to use Visit http://www.dovepress.com/testimonials.php to read real quotes from published authors. 